
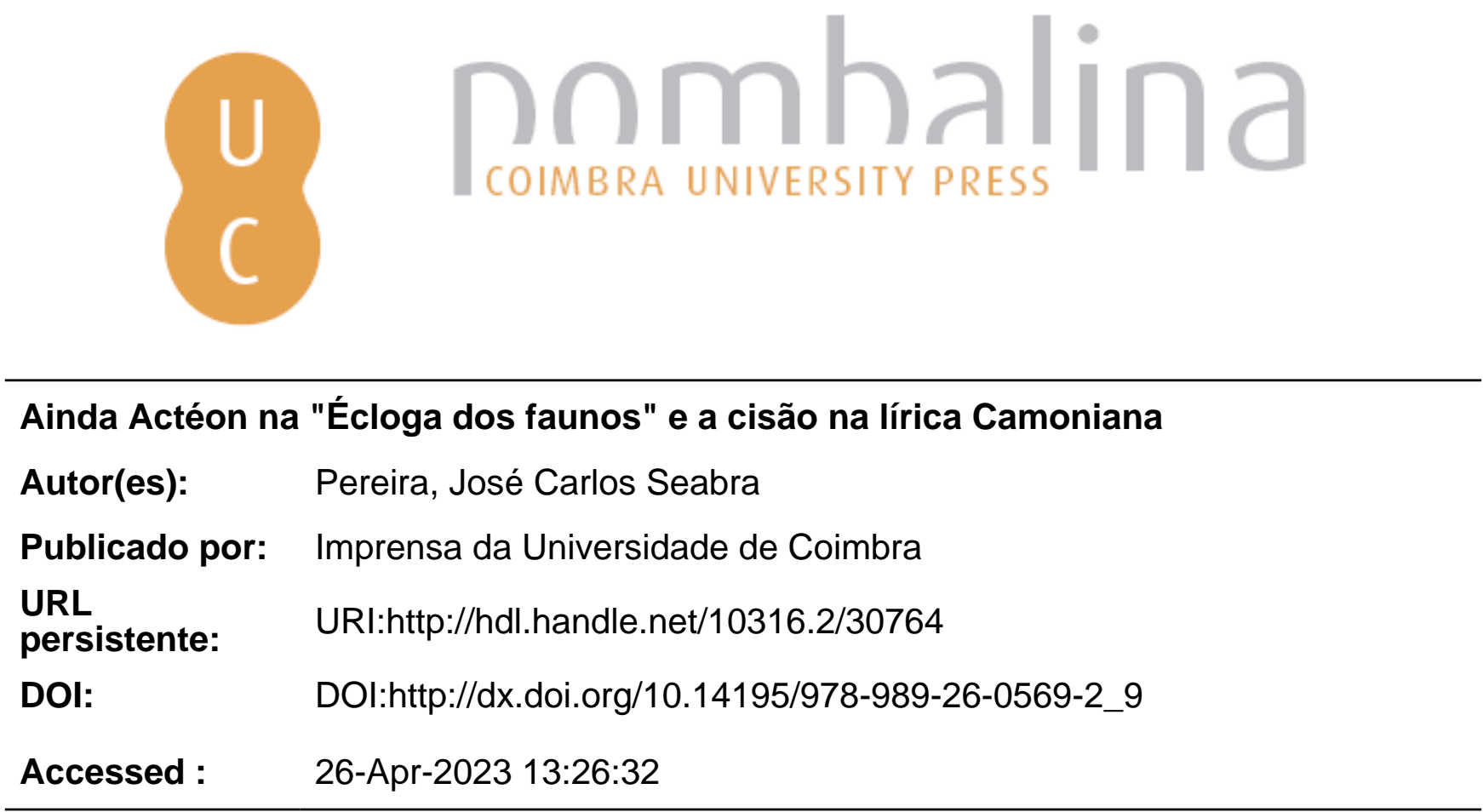

A navegação consulta e descarregamento dos títulos inseridos nas Bibliotecas Digitais UC Digitalis, UC Pombalina e UC Impactum, pressupõem a aceitação plena e sem reservas dos Termos e Condições de Uso destas Bibliotecas Digitais, disponíveis em https://digitalis.uc.pt/pt-pt/termos.

Conforme exposto nos referidos Termos e Condições de Uso, o descarregamento de títulos de acesso restrito requer uma licença válida de autorização devendo o utilizador aceder ao(s) documento(s) a partir de um endereço de IP da instituição detentora da supramencionada licença.

Ao utilizador é apenas permitido o descarregamento para uso pessoal, pelo que o emprego do(s) título(s) descarregado(s) para outro fim, designadamente comercial, carece de autorização do respetivo autor ou editor da obra.

Na medida em que todas as obras da UC Digitalis se encontram protegidas pelo Código do Direito de Autor e Direitos Conexos e demais legislação aplicável, toda a cópia, parcial ou total, deste documento, nos casos em que é legalmente admitida, deverá conter ou fazer-se acompanhar por este aviso.

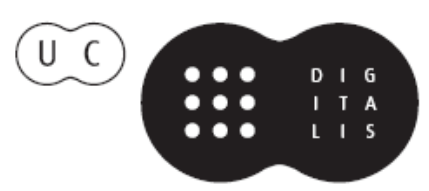




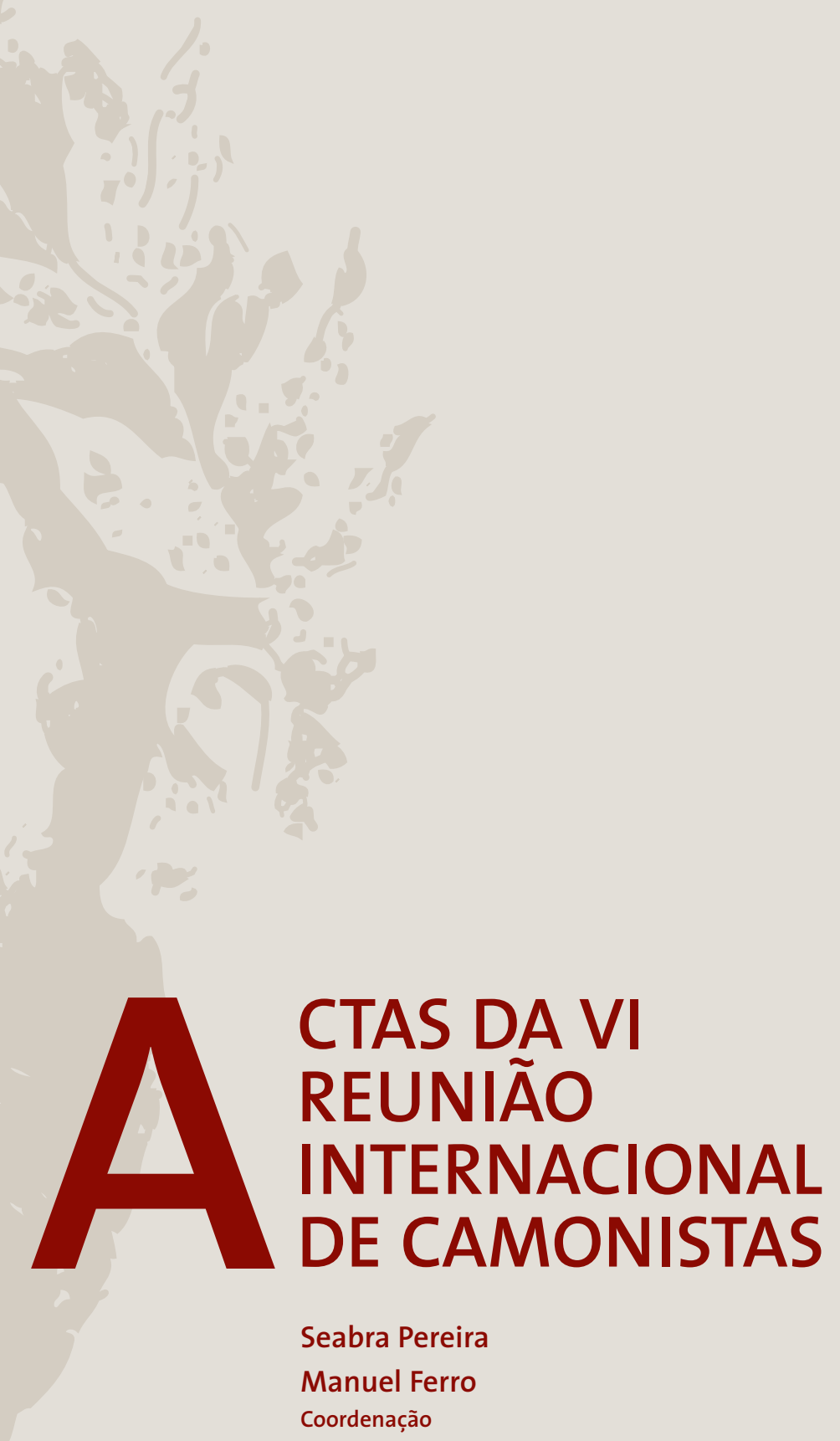


José Carlos Seabra Pereira

Universidade de Coimbra

\section{AINDA ACTÉON NA "ÉCLOGA DOS FAUNOS" E A CISÃO NA LÍRICA CAMONIANA}

1. O «caso de Actéon» ganha valor culminante na construção textual da écloga artística "As doces cantilenas que cantavam", enquanto o lemos sob o efeito da enaltecedora conotação que no poema multimodamente se gera. Recebendo conformação paralela à das narrativas heróicas, se não épicas - proposição, invocação (por litotes), dedicatória e narração (com seus sumários e cenas, com descrições, digressôes especulativas e esboços de episódios, - a écloga vê-se autorizada com oportunas convocaçóes de tópicos fundamentais da poética camoniana (nomeadamente a garantia do saber de experiência feito) e vê-se corroborada por via retórico-estilística na sua promoção de categoria genológica, na medida em que aqueles elementos técnico-compositivos são acompanhados por lances retóricos de eloquência grave e por estilemas de enfatização (hipérboles, por vezes invertidas, acumulaçôes, etc).

Esse valor culminante do "caso de Actéon", assim sobredimensionado, advém primariamente de esse breve (e truncado) episódio surgir a rematar a extensa e globalizante evocação de exemplos (históricos, lendários, míticos) da força imprevisível e incoercível, implacável e inapelável, do desejo amoroso e, no fundo, da omnipresença e omnipotência do Amor e das extremadas imposiçóes da sua índole tão versátil como o Banquete platónico a induzia da filiação em Afrodite Pandemos, deusa do desejo brutal, e em Afrodite Urânia, deusa das afeiçôes etéreas.

Nesse sentido, o comportamento e a (des)dita de Actéon vêm culminar a longa e omnifacetada evocação de histórias de grandes casos de amor - contrariados ou incorrespondidos, infelizes ou malditos ab initio, transgressores ou misteriosos -, conducentes ou conduzidos às mais violentas experiências de sofrimento psicológicomoral e de dor corporal pela interferência de outras paixóes, pela acção de césares e de deuses, de outros poderes ou interditos civis e religiosos, etc. A consequente metamorfose de Actéon em cervo vem culminar a consequente teoria de metamorfoses com que o discurso (pretensamente sedutor e inelutavelmente admonitório) do segundo sátiro ilustra a doutrina invocada pelo primeiro fauno: se este lembra que o Amor, como essência do divino, é fundamento e origem de toda a Criação e assim advoga, pro domo sua, a extensão da vivência do Amor a todo o criado, o segundo sátiro - após uma síntese inferencial daquela doutrina, objecto ainda de dois rappels amargamente irónicos (ou só contra-irónicos numa leitura da «amertume du coeur» em clave de ascese 
e crescimento espiritual...) - evoca e descreve a metamorfose dos grandes e malditos amorosos nos seres brutos e nas coisas dos três reinos naturais, manifestando desse modo (tão ambivalente!...) a presença do Amor em toda a roda do horizonte.

Com essa disfórica ambivalência, a chamada «Écloga dos Faunos» contraria o mais provável horizonte de expectativas do leitor (... e da inércia histórico-literária). Julgando que, sobre aquele fundo de suavidade amorosa que desde a dedicatória da $2^{a}$. edição das Rimas se enaltece nas éclogas camonianas, vai encontrar uma apoteose da perspectiva eudemónica do Homem renascentista e das suas poéticas clássicas, acaba por constatar que esta "Écloga dos Faunos» afinal corrói esse modelo de conexão pletórica de amor e mundividência - aquele em que uma vivência desinibida de erótica hedonista integrava e culminava uma experiência de euforia naturalista num contexto de pansensualidade irradiante. Mas só à medida que se interna no universo ficto deste desinquietado e inquietante discurso bucólico é que o leitor gradativamente vai suspeitando e descobrindo que a écloga camoniana não vem corroborar a ode «Naquele tempo brando», enquanto sequência pletórica e consumação hedonista dos apelos propiciatórios dos sonetos «Está-se a Primavera trasladando» e «Se as penas com que Amor tão mal me trata» (com suas variaçóes dos tópicos articulados de envolvente e estimulante locus amoenus, de acicatante carpe diem, de assediante collige, uirgo, rosas).

Assim, ao chegar ao «caso de Actéon», estará o leitor predisposto para nele contemplar a ironia trágica na personificação dolorosa da inconsumação do amor (e também para ponderar a ironia trágica na cisão íntima do sujeito) - sondando nesta reexploração camoniana do mito de Actéon uma «função projectiva» correlata da que Eduardo Lourenço pioneiramente evidenciou, ao caracterizar o poeta como "Camóes-Actéon, homem de Desejo» e ao analisar a dialéctica existencial e ontognoseológica que como tal transfunde nos seus poemas ${ }^{1}$.

2. Começando a desenvolver a configuração da sua diegese por uma narração que, através de elementos descritivos e de remissôes culturalistas, induz na leitura uma predisposição aprazível para recepção de relato ameno de experiências eufóricas, a écloga não deixa de se reconduzir à organização dialogal do discurso genologicamente canónico. Desde que o faz, empresta sensível dramatismo à elocução dos dois sátiros (sendo especialmente perturbante a ênfase emocional na longa e tensa fala do segundo fauno); mas ganha também a dramaticidade forte que remove a figura do narrador do horizonte receptivo da leitura linear e a sujeita até a esbatimento na memória da leitura tabular, em favor de uma sugestão empática de presentificação da acção e do conflito (exteriores e interiores). É na extrema dessa progressão dramática que sobressai a exemplaridade de "o caso de Actéon».

Lírica e dramática, a écloga especifica-se, entretanto, como tensão e ordem trágica, com sua acção elevada e seus conflitos de personae nobres a suscitarem o terror e a piedade - pela insuspeita vivência da liberdade na necessidade, num jogo existencial de que o meneur é o amor - e a propiciarem, por mitridática catarse, o aprofundamento da auto-consciência humana. É na extrema dessa experiência trágica da condição

\footnotetext{
${ }^{1}$ Eduardo Lourenço, "Camóes-Actéon", ensaio de 1970 recolhido in Poesia e Metafísica - Camöes, Antero, Pessoa, 1ª. ed., Lisboa, Sá da Costa Editora, 1983, pp. 11-30.
} 
humana e desse avanço na auto-reflexividade que «o caso de Actéon» surge como exponencial.

Todavia, essa feição trágica da experiência amorosa e existencial - ausente das Metamorfoses e dos Salices matriciais - só se concretiza porque o amor e a circunstância do eu (e o próprio comportamento com que o eu a si mesmo se surpreende ou controverte) assumem feição de envolvência ominosa e de ironia trágica. É na extrema desse processo de envolvência ominosa e de ironia trágica que se consuma «o caso de Actéon».

Em rigor, os sinais ominosos que vão pontuando, primeiro, a narração introdutória e, depois, a evocação das histórias exemplares de grandes amorosos metamorfoseados, são, eles mesmos, elementos da ironia estrutural da écloga, pois só mais tarde, em movimento retrospectivo da leitura, se torna perceptível o seu valor pressago e sinistro, bem como a sua integração no devir adverso e na derrogação das expectativas de apoteose da erótica hedonista e da euforia naturalista próprias do Classicismo renascentista, que primeiramente puderam ser alimentadas nas dramatis personae e no leitor, através da enganosa activação de convençôes genológicas e periodológicas.

Tudo é dúplice no devir da écloga em que cada sujeito se encaminha (ou julga encaminhar-se por si mesmo) num trajecto que crê e quer de consumação eufórica do desejo do seu bem e, logo, de realizaçáo plena de si mesmo, mas que afinal se revela via armadilhada de engano e/ou de castigo. Assim cada um se vê arrastado para a fatal perdição de si mesmo - por vezes através da figura da fragmentação física, corporizando a desagregação ou a alienação em que, no fundo, desde o plano psicológico-moral até ao plano ontológico, consiste aquela perdição.

3. O narrador começa por propor-se cantar pela escrita as «doces cantilenas» dos semícapros deuses (vv. 1-2)... que só desgraças afinal evocarão. No dia votado à contemplação das ninfas no banho, com a aurora «já nacia / aos ditosos amantes nova pena» (vv. 89-90)... afinal sem compensação. Aliás, o próprio narrador antepóe ao episódio de encanto e adversidade um princípio de dolendi uoluptas ("que Amor de alegres mágoas se sustenta»), afinal versão mitigada da ameaçadora natureza paradoxal do Amor ("Que o moço Idálio quis nesta ciência / que se compadecessem dous contrários» (vv. 127-128), que fica a pairar sobre a narração e as falas subsequentes.

A narração ("consenti que a minha Égloga se conte»), inicia-se com as circunstâncias de lugar e tempo («No cume do Parnaso, duro monte») e prossegue com o episódio do casual achamento desse «encoberto» e ímpar locus amoenus por «ũa linda Ninfa por acerto / perdida da fragueira companhia» (vv. 37-66). Apresenta-se, pois, à leitura linear como momento e espaço de vivência da euforia naturalista; e, mau grado a parcial dissonância, premonitória, da perífrase sobre a violeta, «a flor que dos amantes / a cor tem magoada e saudosa", e a insuspeitada mise en abyme ominosa da «espessa mata, mensageira / da futura cilada», parece preludiar a sua intensificação em quadro de experiência de erótica hedonista (provavelmente mediante os tópicos do banho, do carpe diem e do collige, uirgo, rosas). Na leitura tabular, porém, valerá por abertura enganadora, pois tal não se consumará; e terá funesta desenvolução a efectiva comparência daquelas funçóes tópicas.

Essa ninfa, que depois consigo arrastará outras para uma situação a que terão de escapar-se, fez essa maravilhosa descoberta «cansada já da caça vindo um dia» (v. 70)... 
tal como Actéon assim fará a descoberta da beleza feminina a cujo fascínio talvez não tenha podido eximir-se e que, em todo o caso, lhe acarretará terrível punição.

Antes da cena do banho, a narração do passeio das ninfas pelo paradisíaco monte (vv. 91-111) está semeada de excitantes pormenores de gozo sensível... e de insuspeitos prenúncios dos «casos» subsequentes. Uma ninfa faz tranças «havendo por pesado o desconcerto" dos cabelos, ao passo que depois seráo os desconcertos do desejo amoroso e o máximo desconcerto do mundo constituído pela recusa desse desejo que funestamente imperarão. As primeiras ninfas a serem identificadas são Dinamene e Efire «a que topara / nuas Febo num rio, e encobriram / seus delicados corpos n'água clara", tal como em breve a todas acontecerá sob os olhares cúpidos dos faunos. Indo "pelo viçoso monte alegres» semelhavam «no Céu largo as nítidas estrelas», quando seguidamente, após atiçarem o fremente enamoramento dos faunos, se mostrarâo tão indiferentes ao seu apelo amoroso e ao seu sofrimento quanto o «luzente gado» sidério, que no remate da écloga será sinédoque daquele entorno físico de beleza tão plácida quanto ironicamente indiferente perante a angústia humana da dor e do abandono ${ }^{2}$.

A cena tópica do banho das ninfas (vv. 136-141) não se centra na excitante contemplação especular da beleza erógena do corpo feminino, em que investem a ode "Naquele tempo brando" ${ }^{3}$ e outras representaçóes da Venus Naturalis (distinta da Venus Coelestialis). Antes culmina o vão crescendo da euforia sensualista, desembocando depressa na fuga precipitada e na frustante perseguição amorosa... e preludiando, por mise en abyme, a cena plausivelmente descrita nas duas oitavas expurgadas ${ }^{4}$ à evocação do "caso de Actéon» e que fatal lhe seria.

Logo no início dessa amorosa perseguição, um dos primeiros requestos da fala do primeiro sátiro constitui rebuscada variante especular do tópico collige, uirgo, rosas («Posto que belas n'água vos vejais, / à fonte não creiais, / que vos traz enganada sua vingança / desta nossa esperança, que enganais.»)... e antecipa o que, em idêntico («Ninfas, digo que minto; / ...») reflexo fiel da evolução disfórica, acontecerá a Actéon «Tudo isto Acteon viu na fonte clara, / onde a si de improviso em cervo viu».

O início da captatio beneuolentiae por parte do segundo sátiro enquadra a síntese das razóes inferenciais que o primeiro fauno aduzira («onde não houve cousa que se achasse, / animal, erva verde, ou pedra dura, / que em seu tempo passado não amasse, / nem a quem a afeição suave e pura / nessa presente forma não mudasse») num desafio às ninfas - «Se vós fostes criadas na espessura, / ... / porque náo deixareis também memória / de vós, em namorada e longa história?» - que preludia a evocação de numerosos casos de amores tão grandes quanto infelizes e se constitui, assim, mais em ameaça maléfica de risco e desdita do que em promessa benigna de ventura e gozo.

\footnotetext{
${ }^{2}$ Tal qual ocorre noutros poemas relevantes da lírica camoniana, mormente no magnífico e lancinante soneto "O céu, a terra, o vento sossegado».

${ }^{3}$ Como, aliás, Os Lusíadas (cf. Carlos Ascenso André, "O nu: o tratamento em Os Lusíadas de um tema renascentista", in Revista da Universidade de Aveiro/Letras, 1984, nº 1, pp. 193-212).

4 Porventura já sob o efeito da alteração anti-eudemónica da atmosfera histórico-cultural na Europa e, em particular, em Portugal, o censor das Rimas suspende, perante esse passo da Écloga dos Faunos, a inteligente compreensão adoptada em 1572 perante o "fingimento" poético d'Os Lusíadas. De facto, a edição de 1595 das Rhythmas, após a vigésima quinta estância da fala do segundo sátiro, anota (Daqui se tiraram duas oitavas), abrindo a oitava seguinte com o verso "Tudo isto Actéon viu na fonte clara, / ...».
} 
Essa evocação, a que logo de seguida e longamente o catálogo poético do segundo sátiro procede (vv. 299 e segs.), constitui clamorosa ironia de falsa ilustraçáo e de horrenda contradita daquela doutrina ontocosmológica que antes, com suas consequências interpessoais, fora expendida pelo primeiro sátiro. Em digressão glorificante, mas já com dissonante remate, esse primeiro sátiro entronizara o Amor como princípio da criação e lei da sustentação do mundo, da vida, da existência humana: "Das amorosas leis / com que liga natura os coraçóes / andais fugindo, ó Ninfas, na espessura? / ... / Amor é um brando afeito / que Deus no mundo pôs e a Natureza / para aumentar as cousas que criou. / De Amor está sujeito / tudo quanto possui a redondeza; / Nada sem este afeito se gerou. / Por ele conservou / a causa principal o mundo amado, / donde o pai famulento foi deitado. / As cousas ele as ata e as conforma; / com o mundo reforma / a matéria. Quem há que não o veja? / Quanto meu mal deseja, sempre forma.»

Aliás, quando, em último recurso da sua condição de «desditoso amante», o primeiro sátiro inflectira para a persuasão por ameaça, ele mesmo dera a entrever a dúplice natureza do amor («Aquele amor suave, / aquele poder alto, que, forçados, / os deuses obedecem desprezais? / Pois quero que saibais / que contra o fero Amor nunca houve escudo: / o seu costume é vingança em tudo.»), tal como a seu modo fará o segundo sátiro ("Já vos disse que de Amor sempre tiveram / as cousas insensíveis pena e glória.»).

No final da écloga, após «o caso de Actéon», a fala do segundo sátiro toca a amarga ironia ao remeter por antífrase para a recolecção de amores malditos ou defesos e de amorosos sancionados com metamorfose em elementos do entorno físico: «Aqui, ó Ninfas minhas, vos pintei / todo de amores um jardim suave; / ...». Passa, então, ao franco desabafo lamentoso; mas responde-lhe, como ao pescador Aónio e a outras personae do sujeito lírico camoniano, a solidão humana na indiferença do universo físico: «Mas com quem falo, ou que estou gritando, / pois não há nos penedos sentimento? / Ao vento estou palavras espalhando; / a quem as digo, corre mais que o vento». No envoi, em que o narrador regressa, essa indiferença torna-se mais irónica e magoante por a natureza se revestir de plácida beleza e ampliar ainda, de novo com o eco, aquele intransitivo pranto: «Aqui, o triste sátiro acabou, com saluços que a alma lhe arrancavam. / E os montes insensíveis, que abalou, / nas últimas repostas o ajudavam, / quando Febo nas águas se encerrou / cos animais que o mundo alumiavam, / e co luzente gado apareceu / a celeste pastora pelo Céu».

4. Ao cabo desse alto exercício de virtuosismo retórico-estilístico e de culto paragramatismo que é a fala do segundo sátiro - na relação intertextual, por um lado, com todas as consagradas transmissôes das fábulas mitológicas greco-latinas, com Ovídio obviamente, mas também com as mais relevantes obras mitográficas do pensamento, das artes e da literatura legadas pela Antiguidade, com as reexploraçóes medievais e stilnuovísticas, com a canção dita "delle transformazioni» (poema XXIII dos Rerum Vulgarium Fragmenta) e outros textos de Petrarca, com os modelos italianos e castelhanos da pastoral renascente e maneirista ${ }^{5}$, e, por outo lado, com as fontes

5 Américo da Costa Ramalho, "O mito de Actéon em Camóes» in Estudos Camonianos, 2a. ed., Lisboa, INIC, 1980, pp. 45-72; Leonard Barkan, "Diana and Acteon: The myth as synthesis», in English Literary Renaissance, 10, 3 (1980), pp. 33-46. 
da impregnação da écloga (como de toda a poesia camoniana) por platonismo e neoplatonismo, por petrarquismo e por augustinianismo -, "o caso de Actéon» podia ser escolhido por Camóes não só para recurso retórico de encarecimento dos encantos perigosos da mulher (como em passos vários das Rimas e d'Os Lusíadas ${ }^{6}$ ), mas também e sobretudo para papel culminante de exemplaridade pela mesma razão por que Actéon surge no limiar do episódio da Ilha dos Amores n'Os Lusíadas a assumir uma decisiva função catalítica na motivação e desenvolução da narrativa, que está para além da alegorese moral e admonitória ${ }^{7}$. Essa razão não parece ser o seu valor simbólico como figura do Desejo, mas sim como suprema modalidade do desconcerto do mundo ${ }^{8}$.

$\mathrm{Na}$ verdade, embora Actéon se deixe imprevisivelmente arrastar para uma atitude transgressiva de espectarismo e, portanto, protagonize mais uma das histórias de culpa e castigo que desfecham em metamorfose punitiva, não é por esse impulso erótico desviante, mas pela precedente obstinação anti-erótica, que Actéon se torna (contra-) modelar, personificando o viver à margem dos ditames do amor (por alheamento, fechamento, recusa, depreciação, preterição libidinal) e assim contrariando o Amor como génese e ordenação do mundo, opondo-se à causa primeira e às causas segundas da existência segundo a doutrina neo-platónica?

Curiosamente, visto que podia prevalecer-se da cultura e da memória literária dos leitores epocais, o texto desta écloga camoniana dá por adquiridos esses antecedentes comportamentais e psicológico-morais de Actéon. Dispensa-se, pois, quer do relato caracterizador desse apaixonado pela caça, quer de frisar a conexão entre presumível tendência misógina e efectiva atitude de desinteresse pela beleza e pelo potencial amoroso da mulher. Subentendida, essa história e caracterização de Actéon era conhecida dos receptores camonianos como semelhante à de Narciso e também, embora de modo diverso, à de Hipólito.

De facto, Actéon partilha com Narciso quer a descompassada e exclusivista paixão venatória e hípica, quer o consequente desafecto à beleza feminina e ao amor. Hipólito - o análogo do túrbido soneto "Fiou-se o coraçáo, de muito isento,» - aproxima-se não só pela veneração casta e quase mística por Ártemis em detrimento de Afrodite (e, por isso, «vive num mundo idealizado, sem aprendizagem nem progresso, [...] avesso à condição humana»), mas também pelo "perigoso culto de auto-suficiência e narcísico comprazimento, que confunde com Ártemis» ${ }^{10}$. Actéon partilha em particular com Narciso a cena de auto-contemplação na especularidade aquática e o rasgo de auto-

\footnotetext{
${ }^{6}$ Américo da Costa Ramalho, loc. cit., pp. 51-55. Note-se, no entanto, que na ode «Fogem as neves frias» já a evocação melancólica do destino de Actéon preludia o "treno à caducidade e incerteza da vida humana».

${ }^{7}$ Sobre esse valor alegórico, desde Faria e Sousa entendido como visando D. Sebastiấo, veja-se o ensaio citado de Américo da Costa Ramalho, pp. 55 segs.

${ }^{8}$ Vítor Manuel de Aguiar e Silva, Camöes: Labirintos e Fascínios. Lisboa, Ed. Cotovia, 1994, p. 137 (ensaio "Função e significado do episódio da "Ilha dos Amores" na estrutura de Os Lusíadas») e pp. 155-159 (ensaio "O mito de Actéon como alegoria e como símbolo na poesia de Camóes»).

9 Vítor Manuel de Aguiar e Silva, "O mito de Actéon como alegoria e como símbolo na poesia de Camôes», in Camóes: Labirintos e Fascínios, pp. 157-159.

${ }^{10}$ Maria do Céu Fialho, "Afrodite e Ártemis no Hipólito de Eurípides», in Máthesis, Viseu, no 5, 1996 , pp. 33-51 (especialmente pp. 38-39, 43, 47).
} 
reflexividade... para um efeito reverso (mas porventura não de todo inverso ${ }^{11}$ ). Para a mitocrítica tradicional, a contemplação fascinada de Narciso nas águas leva à fixação objectal em si mesmo (e no mesmo de si); a vertigem especular de Actéon confronta-o com a cisão de si mesmo no outro (de si mesmo).

Narciso vê-se na água e, não obstante Ovídio sugerir que é na sombra da sua imagem que se revira, nela se reconhece embevecidamente, reforçando o seu sentimento de identidade até à fixação fascinada - e a fábula mítica torna-se uma síntese alegórica de hiper-identidade, mas de irónica apoteose (ilaquiante, esterilizante, destrutiva) dessa identidade do sujeito. Aliás, a lírica de Camóes como que alerta para esta amarga ironia do exemplo de Narciso, quando na Écloga «Ao longo do sereno» nos mostra já como «nas águas cristalinas triste estava / Narciso, que inda olhava n'água pura / sua linda figura delicada», e sobretudo quando no soneto "Dizei, Senhora, da beleza ideia:» insere um insuspeitado omen no sibilino remate "fugi das fontes: lembre-vos Narciso.».

Por seu turno, o Actéon que se vê na água e nela se descobre transformado em cervo, não é evocado como na ode «Fogem as neves frias» apenas porque "perdeu (...) a natural figura», mas também, nesta écloga dos Faunos, porque nessa especularidade pávida se reconhece ainda, na medida em que ainda se pensa como Actéon, como sujeito outro no corpo e na voz, mas o mesmo no espírito. No fundo, tal fábula mítica, unindo o espelho da "fonte clara» ao espelho da consciência gradativamente mais lúcida, torna-se uma síntese alegórica de conhecimento pela cisão, enquanto experiência exponencial do curarum conflictus e do aprofundamento antropológico.

É nisso, de resto, que o texto desta écloga de Camóes se concentra quando chega ao «caso de Actéon». De facto, logo no início da narração antecipa concisamente o desenlace da diegese no fundo mitográfico - «(...) escolher nos seus galgos sepultura»; e depois explora a metamorfose punitiva - «em cervo transformado» por Diana, como analogicamente Francesco por Laura no paradigmático Canzoniere petrarquiano - em favor de outros focos de atenção.

Um, canónico desde Ovídio, mas encadeado por Camôes numa estruturante isotopia de ironia trágica, reside na cena do banho de Diana e da fruiçáo libidinal (e da excitação concupiscente) de Actéon ao observar furtivamente a beleza esplendorosa do corpo desnudo da deusa caçadora - cena decerto contemplada nas duas oitavas retiradas, conforme nota de editio princeps de 1595, mas que, apesar desse expurgo, permanece alusivamente avivada na memória literária de receptores a priori adestrados (e depois estimulados pelo texto camoniano) a convocarem ao seu horizonte de cooperação interpretativa os intertextos hetero-autorais e os intertextos homo-autorais (fora e dentro desta mesma écloga) atinentes a tal topos, que releva primordialmente da encenação da euforia naturalista e da consumação da erótica hedonista peculiares dos surtos de eudemonismo clássico-renascentista (e que na ode «Naquele tempo brando» recebe esse tratamento).

${ }^{11} \mathrm{Na}$ medida em que, sobretudo para o receptor cuja competência comunicacional está já informada pelas modernas explorações simbólicas dos mitemas partilhados, Narciso póe em cena, e do mesmo passo, permite pôr em causa mais a (hiper)identidade do que a sexualidade onanista; e na medida em que a condição de homem-Narciso, sobretudo quando a modernidade literária o cinde entre um Eu e um outro que também é $E$, conduz geralmente à morte ou à loucura... 
Outro foco de atenção, qualitativamente inovador, e morfologicamente sobreposto à fábula mítica de Narciso, consiste na cena da contemplação especular de Actéon na superfície reflectora da água. Prevalecendo-se do valor de indagação e adivinhação tradicionalmente atribuído à água-espelho, e deslocando em perspectiva moderna a antinomia do mito de Narciso ${ }^{12}$ - o qual (sabemo-lo melhor desde Bachelard) se pensa ao mirar-se na imagem reflectida e, por vezes, para sublimar o desejo em ordem a um ideal $^{13}$-, Camóes explora insolitamente essa cena em processo cognitivo, com avanço da auto-reflexividade pela experiência da cisão ${ }^{14}$.

Assim, num Camões que (desde Os Lusíadas até às Rimas, passando pelo Auto chamado dos Enfatriôes, com o criado Sósia «perdido em dois») problematiza a condição identitária do sujeito, com o "caso de Actéon" o que se vê posto em causa e lacerado é desde logo o ufano culto da identidade do eu, peculiar do Homem renascentista - orgulhoso da sua unidade coerente de dotes e potencialidades, da sua afirmaçáo e expansão no espaço e no tempo, da sua capacidade de conhecer e dominar o mundo, de comandar e fruir na imanência terrena as relaçóes interpessoais e a sua circunstância.

Assim, à luz do "caso de Actéon», a «hipertrofia do eu» só poderá exercer-se em regime agónico; e insolitamente agónica há-de ser a componente narcísica que comportar, na estratégia de auto-sobrevalorização do Poeta pela avocação de uma superior cota de sofrimento existencial, a construção de uma biografia paradigmática segundo a estética do desafogo ${ }^{15}$.

Assim, incorporando o "caso de Actéon" e explorando-o em lugar de cimeira importância estrutural, a chamada «Écloga dos Faunos» não só corrobora a sua valência de contra-apoteose do modelo eudemónico renascentista numa das suas conexôes eufóricas de amor e mundividên cia $^{16}$, mas corrói também esse modelo renascentista no plano ontognoseológico - minando o optimismo antropológico e a sua racionalidade de confiança na identidade pletórica do eu. De ambos os modos, esta écloga abre caminho para a condição de crise (e de busca noética, e de luta ética e espiritual pela superação) que será a do Homem na poesia do Maneirismo e no devir da lírica de Camóes entre a libido sentiendi e a libido sciendi...

12 Já em Sá de Miranda, o Gil da «Écloga Basto» chora ao ver-se na água da fonte, pois reconhece então que se tornara velho e não podia mais rever-se nessa imagem (muito menos enlevar-se com essa sua mudada figura), perdendo-se antes em amargurada meditação ( «... / a tal desacordo vim, / Que quando tornei em mim / Bom espaço o Sol correra.»).

${ }^{13}$ Gaston Bachelard, L'eau et les rêves. Essai sur l'imagination de la matière. Paris, Librairie José Corti, $17^{\text {e }}$ Réimpression, 1981, pp. 31-40.

${ }^{14}$ Cf. José Carlos Seabra Pereira, Para o estudo das incidências augustinianas na Lírica de Camóes. Ponta Delgada, Universidade dos Açores, 1984 (Sep. de Actas da IV Reunião Internacional de Camonistas), pp. 446-448.

15 Vide Maria Vitalina Leal de Matos, "Auto-retrato de Camóes: o soneto "O dia em que eu nasci...”", in Ler e Escrever. Ensaios. Lisboa, I.N.C.M., 1987, pp. 33-47, e Thomas F. Earle, "Autobiografia e retórica numa canção de Camões», in Arquivos do Centro Cultural Português (Lisboa - Paris, Fundação C. Gulbenkian), vol. XXIII, 1987, pp. 507-521.

16 Vítor Manuel de Aguiar e Silva, Maneirismo e Barroco na Poesia Lírica Portuguesa. Coimbra, 1971, pp. 290-291; veja-se, todavia, idem, "Amor e mundividência na lírica de Camôes», in Camóes: Labirintos e Fascínios, pp. 163-177. 
Além disso, em nosso entender, o texto da écloga camoniana investe noutro vector, até agora inadvertido, de abertura inesperada da narrativa - inesperada, fora da glosa moralista dos remorsos do poeta-Actéon, que "anchor de' miei can' fuggo lo stormo» como Petrarca. Rápida e liminarmente desincumbida da informação sobre o destino de Actéon segundo a fábula mitológica, a écloga camoniana volta-se, de modo diferente do que a "Fábula do Mondego» mirandina ou os Poemas Lusitanos de António Ferreira, para o retrato em linha de fuga, focando o (anti-)herói na errância, não balizada, com que ele reage à consciencialização da metamorfose física: «Mas, como o triste amante em si notara / a desusada forma, se partiu.»

Esse enfoque acentua-se no processo irónico de desencontro e identificação, ou de identidade cindida no mesmo e no outro de si, até à suspensáo indeterminada (no silêncio transicional que a composição da écloga faz seguir a «-É este, é este, o eco respondia.»). A ironia trágica que subtende toda a écloga acentua-se então subtilmente, graças ao jogo de lances de identificação (ipseidade, reiteração): as exclamaçôes «É este, é este», o seu reforço pelo eco (fenómeno físico, aliás, resultante da metamorfose de Eco, a amorosa rejeitada por Narciso!...), a deixis pronominal e adverbial («a si [...] viu», «ali o topara», "em si notara», "Os seus, que o não conhecem, o vão chamando; / e estando ali presente, o vão buscando", "e a multidão dos cáes contra ele vinha»).

Camóes póe assim Actéon a viver - desde a afinidade narcísica até à perturbação anti-narcísica, ou, melhor, desde a vertigem narcísica eudemónica até à vertigem narcísica agónica - a experiência paradoxal de rever-se o mesmo e o outro (de si mesmo), de refracção de si mesmo no outro de si mesmo, de chamamento para se dar à morte no outro de si mesmo...

Visto por esse prisma, o tratamento de «o caso de Actéon» nesta écloga camoniana parece antecipar o problemático reentendimento moderno da fábula de Narciso, cruzando a sua exploraçáo com o tema do duplo - náo porque a imagem desaparecida vá viver a sua vida própria (como em alguns modernistas) mas porque, por um lado, a experiência de Actéon implica o Eu e o transforma, e porque, por outro lado, o duplo de Actéon é diferente do Eu e, no entanto, a ele idêntico. Nessa perspectiva proto-moderna se integraria, então, o próprio eco que, no processo de reconfiguração ou reconstituição da identidade, encaminha para a verdade da existência.

5. Talvez se possa, por conseguinte, arriscar um pouco mais na hermenêutica prospectiva desse processo de exploração do mito de Actéon como contraface pósrenascentista do mito de Narciso na dialéctica amorosa e ontognoseológica da lírica camoniana.

Nesse sentido, convém ter presente que, iconologicamente ligado a Ártemis/ Diana, o cervo é símbolo de agilidade e velocidade, de potência viril e desassossegante desejo ${ }^{17}$, mas também de turvação e medo - faceta simbológica talvez não despicienda numa écloga em que toda uma retórica do medo precede «o caso de Actéon» (medo de frustração do desejo ou de perda do bem desejado, medo perante forças alheias e medo perante si mesmo enquanto ser de desejo e memória).

${ }^{17}$ Como na nossa trovadoresca (cf. S. Reckerte e Helder Macedo, Do Cancioneiro de Amigo. Lisboa, Assírio \& Alvim, 1976, pp. 19, 59, 97-98, 113-114, 207, 213) e na tradição peninsular tão familiar a Camóes. 
Convém também ter presente que, tal como a beleza de Narciso (de quem Actéon é a contraface em cisão) morre para ganhar a forma de certa flor bela, o narciso, que, nascendo nas tumbas, evoca a morte mas também mostra a fertilidade da natureza e simboliza o devir da vida e o desejo, e tal como Eco (cuja fábula de amor trágico fora lembrada a meio da teoria dos metamorfoseados e, por mise en abyme, reemerge no eco que, com cruel ironia, fala a Actéon da identidade maldita) evoca a noção do duplo e vale como símbolo arquetípico de uma regressáo e de uma passividade que podem não ser senão estado passageiro e via de transformação, também a iconologia do cervo, para além da associação emblemática à deusa caçadora, simboliza tradicionalmente a fecundidade, os ritmos de crescimento, os renascimentos. A essa luz, a metamorfose de Actéon actua como mais um elemento de ironia trágica se lermos a narrativa da écloga como votando Actéon à «sepultura» (na boca dos seus próprios cães), ou actua como potencial de avanço cognitivo e de ascensão amorosa se lermos esse episódio eglogal como narrativa aberta, que deixa indeterminado o destino do sujeito após a constatação especular da sua metamorfose e no decurso da reacção auto-reflexiva.

Nessa deriva, os valores co-textuais e intertextuais que condicionam a validade das concretizaçóes literárias deste passo da «Écloga dos Faunos» não favorecem que a cooperação interpretativa convoque em clave eufórica a simbolização da atracção erótica e do ardor amoroso a que o cervo aparece associado noutras representaçóes emblemáticas onde figura ao pé do par Afrodite e Adónis. Em contrapartida, essa cooperação interpretativa deverá ter presente que, sem se opor diametralmente ao valor simbólico de sexualidade viril que lhe atribui longa tradição pagã (depois cristianizada na literatura medieval), a figura do cervo aparece na arte, desde a Antiguidade, como ente de espírito melancólico e sujeito a um mal de amante malum immedicabile, que em vão procura curar com certa erva que leva à boca (tão em vão como o sabia o Apolo a quem Dafne foge nas Metamorfoses de Ovídio e na écloga de Camóes).

Ora, é com essa sensibilidade dilacerada e esse espírito melancólico que o Actéoncervo se aproxima do Narciso maneirista e do próprio sujeito poético na lírica do Maneirismo e de Camóes ${ }^{18}$ - tanto mais quanto do potencial simbólico da iconologia do cervo faz parte também a representação figural da poesia lírica, pois muitas vezes o cervo ama e acompanha a musa Erato.

Assim sendo, para onde se deverão orientar as hipóteses interpretativas com que regressemos, após estes passeios inferenciais, à margem de indeterminação semântica do texto eglogal camoniano?

Se o leitor não esquece nem remove do devir da concretização da écloga o rappel de "escolher nos seus galgos sepultura», então na errância do acossado Actéon-cervo, mesmo que haja lugar para fugaz experiência do que vive o Duque shakespeareano de Twelfth Night ${ }^{19}$, não haverá tempo para que o eu (e o outro de si mesmo) siga evolução análoga à do universo sob o efeito da força genesíaca, ordenadora e ascendente que ao Amor, contra a lição da experiência adversa, atribuíam cosmogonias da cultura

18 Cf. Vítor Manuel de Aguiar e Silva, Camóes: Labirintos e Fascínios, especialmente pp. 159 e 227.

19 «Nesse instante fui eu mudado em veado: / e os meus desejos como galgos cruéis e selvagens / não mais deixaram de perseguir-me» (cf. Américo da Costa Ramalho, loc. cit., p. 54). 
ocidental (em especial, de matriz helénica, desde Hesíodo, e de matriz cristã). Assim, Actéon-cervo e o Camóes desta écloga (em que a ninfa primeira busca as irmãs "no centro») não dispóem de tempo para passar a viver o amor como demanda de um centro (re) unificador, que permitiria realizar a síntese dinâmica das suas virtualidades ${ }^{20}$.

Em contrapartida, no avanço da auto-reflexividade, mediante a experiência de cisão e de acossada errância, não só se propicia a eversão dinâmica da fábula de hiper-identidade (bela mas frustrante) que o mito de Narciso comporta, mas abre-se também caminho ${ }^{21}$ para a compreensão de que o amor se torna princípio de divisão e de morte quando se perverte e de que a perversão do amor consiste em o sujeito do enamoramento e do desejo destruir o valor do outro (e assim se destruir nessa lógica egotista, pela boca dos "seus cães») para tentar sujeitá-lo a si mesmo, em vez de enriquecer ao outro e a si mesmo por um dom recíproco e generoso, que faria cada um ser mais e lhe permitiria simultaneamente reconhecer-se em si mesmo, fiel a si mesmo.

Aliás, é na "fonte clara» que o Actéon da écloga camoniana vê Diana e as ninfas banhando-se; com a água da "fonte clara» é que, presume-se, Diana terá aspergido Actéon para o metamorfosear; é na "fonte clara» que Actéon, homem-caçador transformado em animal caçado, se vê a si mesmo e ao outro de si mesmo. Ora, pelas suas águas que mudam continuamente, a fonte não só activa uma mise en abyme da evolução na subjectividade humana ${ }^{22}$, como simboliza a energeia de perpétuo rejuvenescimento el ou equivale a fonte de ensino e aprendizagem... ${ }^{23}$

${ }^{20} \mathrm{E}$, para a minha leitura estruturante da lírica camoniana com teleologia augustiniana (e sua integração superadora de petrarquismo e neo-platonismo), na "Écloga dos Faunos» náo chega ainda o tempo em que, por uma valência psicológica da simbologia dos «cáes» diferente da tradicional exploração moralista de remorsos, a libido atingiria na consciência aquela iluminação que a tornaria força espiritual de progresso ético e religioso, enquanto augustinianamente a memoria rerum conduziria à memoria sui e esta à memoria Dei.

${ }^{21}$ Mesmo sem especularmos com a hipótese de leitura da morte como passagem (em sentido pascal cristão ou em sentido iniciático), que os elementos determinados da semântica do texto desta écloga camoniana não parecem convalidar. O próprio desabafo final do segundo sátiro - «que só na morte tenho as esperanças» - parece dever ser lido como tópico para dizer o mero horizonte de findar dos tormentos pela aniquilação da existência... embora, em termos de imaginação simbólica ou de fenomenologia do imaginário, a leitura da morte como passagem a outro plano ôntico jogasse no remate da écloga com a sugestáo de fronteira (entre o mundo do movimento e da matéria sujeita a mudança e o mundo da eternidade imóvel e do espírito permanente) e com a sugestão de via de peregrinação ou deslocação espiritual que a Via Láctea simboliza tradicionalmente e que aqui poderia ser lida nos dois versos derradeiros: «e co luzente gado apareceu / a celeste pastora pelo Céu.».

22 Por exemplo, em clave de especulação mitocrítica poderia aventar-se que na persistente ambivalência dos elementos simbólicos da diegese "o caso de Actéon" culmina o efeito do desejo pelas "ninfas", cujo fascínio (sobretudo como forma saindo do seio das águas) tanto pode levar à loucura ou provocar a abolição da personalidade, como pode exprimir simbolicamente os aspectos femininos do inconsciente no processo de desenvolvimento da personalidade. Neste caso, a água nefasta ou perigosa (do banho, da aspersão punitiva, da contemplação, da especularidade) ter-se-ia volvido em água fecundante - dando razão aos que, desde Hesíodo, consideram que é a intervenção do amor que distingue essas valências da água...

${ }^{23}$ Aliás, em simbologias edificantes do bestiário medieval, por vezes com inspiração no saltério davídico, o cervo, que deseja a fonte e nala se regenera, representa o homem que faz penitência e se salva. Cf. Ignacio Malaxecheverría (ed.), Bestiário Medieval. Madrid, Ediciones Siruela, 1986, pp. 42-45. 